\title{
銅化合物による心血管障害及び糖尿病治療への実験的試み
}

\author{
桜井弘
}

\section{Copper Compounds Ameliorate Cardiovasclur Dysfunction and Diabetes in Animals}

\author{
Hiromu Sakurai \\ Department of Pharmaceutical Sciences, Suzuka University of Medical Science; \\ 3500-3 Minami-Tamagakicho, Suzuka, Mie 513-8670, Japan.
}

(Received August 31, 2011)

\begin{abstract}
Copper $(\mathrm{Cu})$ is essential for our daily life and it is found at approximately $110 \mathrm{mg}$ in human adults with the body weight of $70 \mathrm{~kg}$, in which this metal occurs at $46 \mathrm{mg}$ in the bone and $26 \mathrm{mg}$ in the muscle. Although Cu exists in the brain (approximately $5 \mathrm{mg} / \mathrm{kg}$ ), liver $(6 \mathrm{mg} / \mathrm{kg})$, kidney $(13 \mathrm{mg} / \mathrm{kg})$, erythrocytes $(90 \mathrm{mg} / \mathrm{L})$, bile $(6 \mathrm{mg} / \mathrm{L})$ and serum $(120 \mathrm{mg} / \mathrm{L})$, its organ-specific distribution is not yet known. In metalloenzymes such as oxidoreductases, Cu is abundantly found and greatly contributes in life functions. In addition, intracellular $\mathrm{Cu}$ transport system has been revealed in connection with iron $(\mathrm{Fe})$ and zinc $(\mathrm{Zn})$ intracellular transport systems. In spite of such great contribution of $\mathrm{Cu}$ in life, no $\mathrm{Cu}$-containing pharmaceutics have yet been known. Under such background, the author and his research group have tried to examine a possibility of $\mathrm{Cu}$ compounds as potential pharmaceutics. In the review, the following topics are concerned; (1) improvement of cardiovascular dysfunction in animals by di-nuclear Cu-asprinate complex on the basis of the results on its reactive oxygen scavenging (ROS) effect, (2) blood glucose-lowering effect of mono-nuclear Cupicolinate complex in streptozotocin (STZ)-induced type 1-like diabetic animals, based on the results on in vitro insulinomimetic activity, and (3) anti-diabetic effect of copper sulfate in animals with regard to the inhibition of $\alpha$-glucosidase activity. These results suggest that copper ion and its complexes are possible seeds for developing Cu-containing pharmaceutics in the future.
\end{abstract}

Key words_— copper complex; pharmaceutics; cardiovascular dysfunction; diabetes

\section{1. はじめに}

1892 年, スイスの化学者ウェルナー（Werner 1866-1919）は，コバルト原子を含む無機化合物は コバルト原子が中心的位置を占め，その周りをアン モニア分子や塩素イオンが全体的に取り巻く立体的 構造をしていると考え，配位説（coordination theory）を提案した。この配位説により，金属原子と 有機化合物やイオンなどの配位子を含む錯体の立体 構造を一般的に解析できるようになった。 その後, 配位説はへモグロビンやクロロフィルなど金属を含 む生体分子の構造と機能を明らかにする上で，極め て重要な考え方となった. ${ }^{1-3)}$ 一方, 1910 年に, ド イツの細菌学者・化学者のエールリヒ（Ehrlich

鈴鹿医療科学大学薬学部（干513-8670 三重県鈴鹿市南 玉垣町 3500-3)

e-mail: hanssakurai@i-next.ne.jp

本総説は, 日本薬学会第 131 年会シンポジウム S04 で 発表したものを中心に記述したものである.
1854-1915）は，当時流行していた梅毒の特効薬サ ルバルサンを合成し，本化合物により疾患が治療で きることを見い出し，化学療法 (chemotherapy) を提案した。 今日の医薬品合成の理念を築いた. ${ }^{2-4)}$ サルバルサンは，無機元素ヒ素（As）と炭素（C） との結合を持つ有機ヒ素化合物の第 1 号である. 化 学療法が提案されて以来, これを配位説と組み合わ せて金属を含む医薬品合成の研究が活発となり，多 くの医薬品が開発された。例えば，コバルト（Co） を含む抗貧血薬 シアノコバラミン，金 $(\mathrm{Au})$ を含 む抗リウマチ薬 金一チオリンゴ酸やオーラノフィ ン, 白金 $(\mathrm{Pt})$ を含む抗がん薬 シスプラチンや亜 鉛（Zn）を含む抗胃潰瘍薬 ポラプレジンクなどが 挙げられる.2,3)これまで臨床的に用いられてきた金 属や半金属原子を周期表に書き込むと Fig. 1 のよ うになる。利用されている金属や半金属元素の種類 は限定的であるばかりでなく，これらを用いる基本 的原理は，この周期表から読みとることは困難であ 
The Periodic Table of the Elements

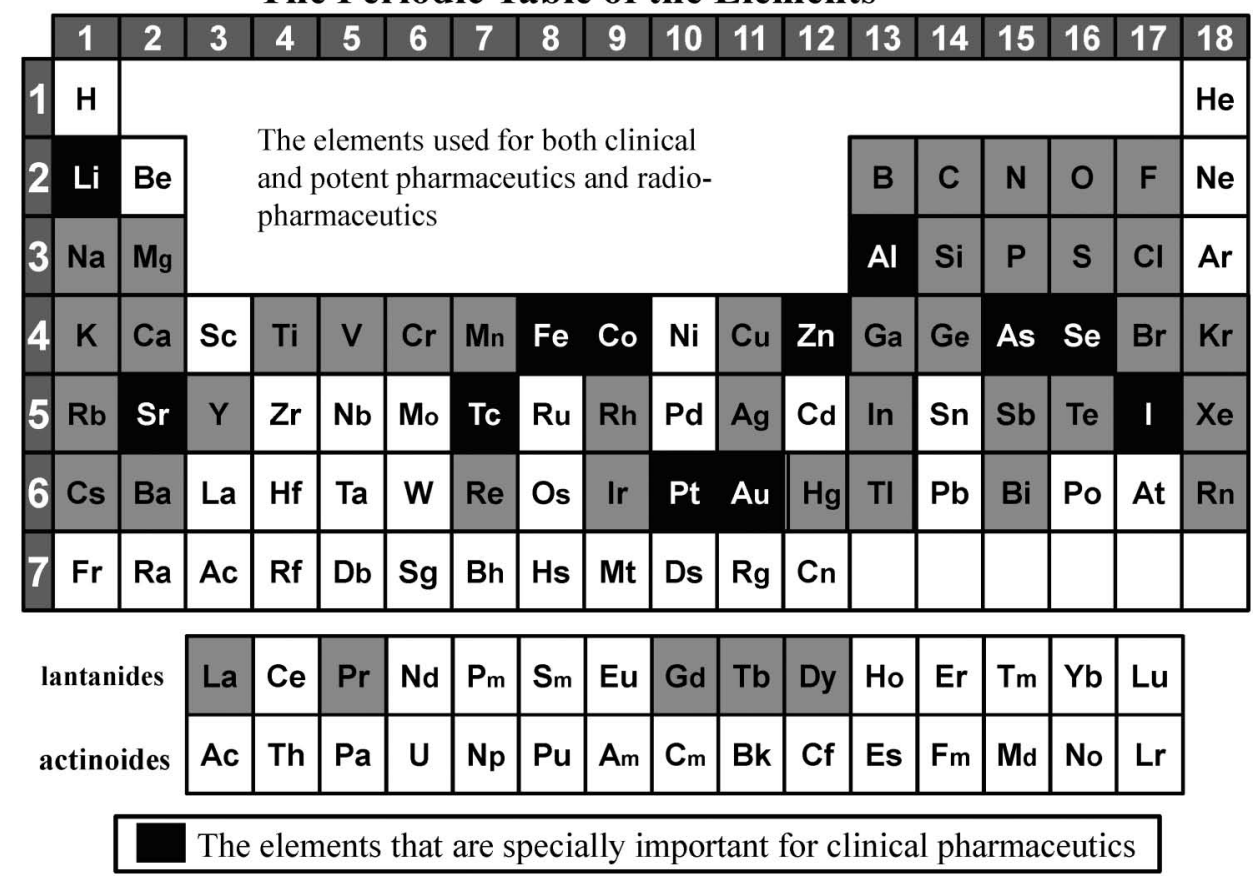

Fig. 1. The Elements Used for Clinical and Potential Pharmaceuics and Radio-pharmaceutics Plotted in the Periodic Table of the Elements

る. 金属含有医薬品 (metal-based drugs 又は metallopharmaceutics）の開発の原理は，周期表にあ らわれる金属や半金属の未知の能力を引き出すだけ でなく，それらに配位子を結合させることにより新 たな機能を持つ医薬品へと開発することであろう. 古代から知られている金属原子でありながら, 確固 たる医薬品を生み出していない典型的な元素に，銅 （Cu）が挙げられる，そこで，本総説では，銅化合 物が持つ薬物活性を紹介しながら，銅含有医薬品の 開発研究は可能かどうかを議論する.

体重 $70 \mathrm{~kg}$ の成人には, 約 $110 \mathrm{mg}$ の銅が存在 し, 骨 $(46 \mathrm{mg})$ や筋肉 $(26 \mathrm{mg})$ に多い。濃度で 比べると, 脳 $(5 \mathrm{mg} / \mathrm{kg})$, 肝臓 $(6 \mathrm{mg} / \mathrm{kg})$, 腎臓 $(13 \mathrm{mg} / \mathrm{kg})$, 赤血球 $(90 \mathrm{mg} / \mathrm{L})$, 胆汁 $(6 \mathrm{mg} / \mathrm{L})$ や血清 $(120 \mathrm{mg} / \mathrm{L})$ であるが，銅の臓器特異的な 分布は知られていない. 3 ,5) 銅は必須元素の 1 つであ り, 哺乳動物では酸化還元酵素を中心とする金属酵 素に多く存在し, 生命機能に直接関与している. 細 胞内銅輸送系は鉄や亜鉛輸送系と連繋し，動的代謝 機構がかなり明らかにされている.6,7)このような重 要な元素であるにもかかわらず，銅イオンやその錯 体が医薬品として用いられてきた例はほとんど知ら れていない。ここでは，(1)複核構造を持つ銅一アス

ピリン錯体が活性酸素消去能を持つことを基盤にし て見い出した心血管障害の改善作用，(2) 銅ーピコリ ン酸錯体の in vitro インスリン様作用を基盤にして 見い出した 1 型類似糖尿病ラットの血糖降下作用及

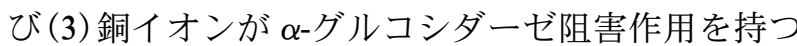
ことを基盤にして見い出したショ糖（砂糖, 二糖 類，グルコース＋フルクトース）を投与した動物に おける抗糖尿病作用についての研究を紹介する。こ れらの研究結果は，銅錯体が医薬品開発のシーズの 1 つとして可能性があることを示しているようであ る.

2. 複核銅ーアスピリン錯体による心血管障害の 改善作用

活性酸素種（reactive oxygen species, ROS) は高 血圧, 動脈硬化症あるいは紫外線による光老化を始

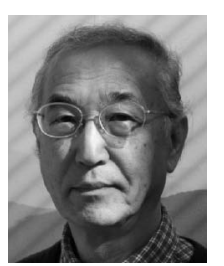

桜井 弘
1971 年京都大学大学院薬学研究科博士 課程修了, 薬学博士. 1972 年京都薬科 大学講師, 1975 年徳島大学薬学部助教 授, 1990 年京都薬科大学教授, 1999 年 分子科学研究所客員教授, 2008 年鈴鹿 医療科学大学薬学部教授, 2011 年東京 工科大学客員教授. ザールランド大 学, イリノイ大学, コンスタンツ大 学, ブランダイス大学で研究. 生命錯 体化学. 
めとして多くの疾患の原因と考えられている，最も 典型的な ROS としてのスーパーオキシドアニオン ラジカル（superoxide anion radical, $\cdot \mathrm{O}_{2}^{-}$）を過酸化 水素 $\left(\mathrm{H}_{2} \mathrm{O}_{2}\right)$ と三重項酸素 $\left({ }^{3} \mathrm{O}_{2}\right)$ とに変換する酵 素，スーパーオキシドジスムターゼ（superoxide dismutase, SOD）は多くの動物の体内に存在し, ROS の攻撃から生体を防御している。すすへての真 核細胞には Cu-Zn-SOD があり，Fe-又は Mn-SOD は原核生物，原生生物及びミトコンドリア内に存在 する. Cu-Zn-SOD では，Cu が活性中心を形成し，

$\mathrm{Zn}$ は酵素の 3 次元構造を保持していると考えられ ており, 作用機構も解明されている. SOD の生体内 濃度は加齢とともに減少するが，酵素であるため体 外からの投与は不可能である。このため, SOD と 同様の配位構造と触媒活性を持つ低分子 SOD 様錯 体が合成され，医薬品として開発する研究が探られ ている. ${ }^{8)}$ 筆者のグループも 1993 年以来，いくつか の錯体を提案している. ${ }^{3,9)}$ この研究の流れの中で 筆者らは，SOD 様活性を持つ銅イオンと解熱・鎮 痛・消炎作用を有し，近年では血小板凝集抑制，抗 がん，紫外線防御作用を持つことが示されているア スピリン（aspirin, asp）とに着目して，銅ーアスピ リン錯体を合成し，構造と抗酸化作用を評価するこ ととした.
銅ーアスピリン錯体は既に 1973 年と 2003 年に合 成され， 2 核錯体 $\mathrm{Cu}_{2}(\mathrm{asp})_{4}$ や $\mathrm{Cu}_{2}(\mathrm{asp})_{4}(\mathrm{DMF})_{2}$ として知られていたが，新たに $\mathrm{Cu}_{2}(\mathrm{asp})_{4}(\mathrm{DMSO})_{2}$ 及び関連錯体として銅ーサリチル酸錯体 $\left(\mathrm{Cu}(\mathrm{sal})_{2}\right)$ を合成し，種々の物性を測定するとともにX 線構 造解析法により詳細な構造を確認した. $\mathrm{Cu}_{2}(\mathrm{asp})_{4}$ $(\mathrm{DMSO})_{2}$ 錯体の 3 次元構造を Fig. 2 に示した.こ こで，Cu-Cu 間の結合距離は $2.632 \AA$ である. ${ }^{10)}$ そ こで, $\mathrm{Cu}_{2}(\mathrm{asp})_{4}(\mathrm{DMSO})_{2}$ と関連化合物の (1) SOD 様活性，（2）ヒト上皮のケラチン生成細胞（HaCaT） 及びヒト皮膚の繊維芽細胞（HHDF）の紫外線 A （UVA）照射下における細胞生存率，（3）ヘアレス マウスにUVA を照射後の皮膚中の ROS 生成率, そして (4) 錯体を投与したマウスの血中及び皮膚中 の銅濃度の定量について研究した. ${ }^{10,11)}$

硫酸銅 $\left(\mathrm{CuSO}_{4}\right), \mathrm{Cu}(\mathrm{sal})_{2}, \mathrm{Cu}_{2}(\mathrm{asp})_{4}(\mathrm{DMSO})_{2}$ 及び Cu-Zn-SOD のスーパーオキシドアニオンラジ カル消去作用 (superoxide anion radical scavenging activity，SSA）は，シトクロム法，ESR スピントラ ップ法及び直接 ESR 検出法を用いて評価したが, 銅イオンと錯体との間には有意差はなく，すべての 化合物は Cu-Zn-SOD が示す SSA の約 $1.6 \times 10^{-3}$ の 活性を示すに留まった。しかし，UVA 照射下の $\mathrm{HaCaT}$ 細胞における生存率は $\mathrm{Cu}(\mathrm{sal})_{2}>\mathrm{Cu}_{2}(\mathrm{asp})_{4}$

(A)
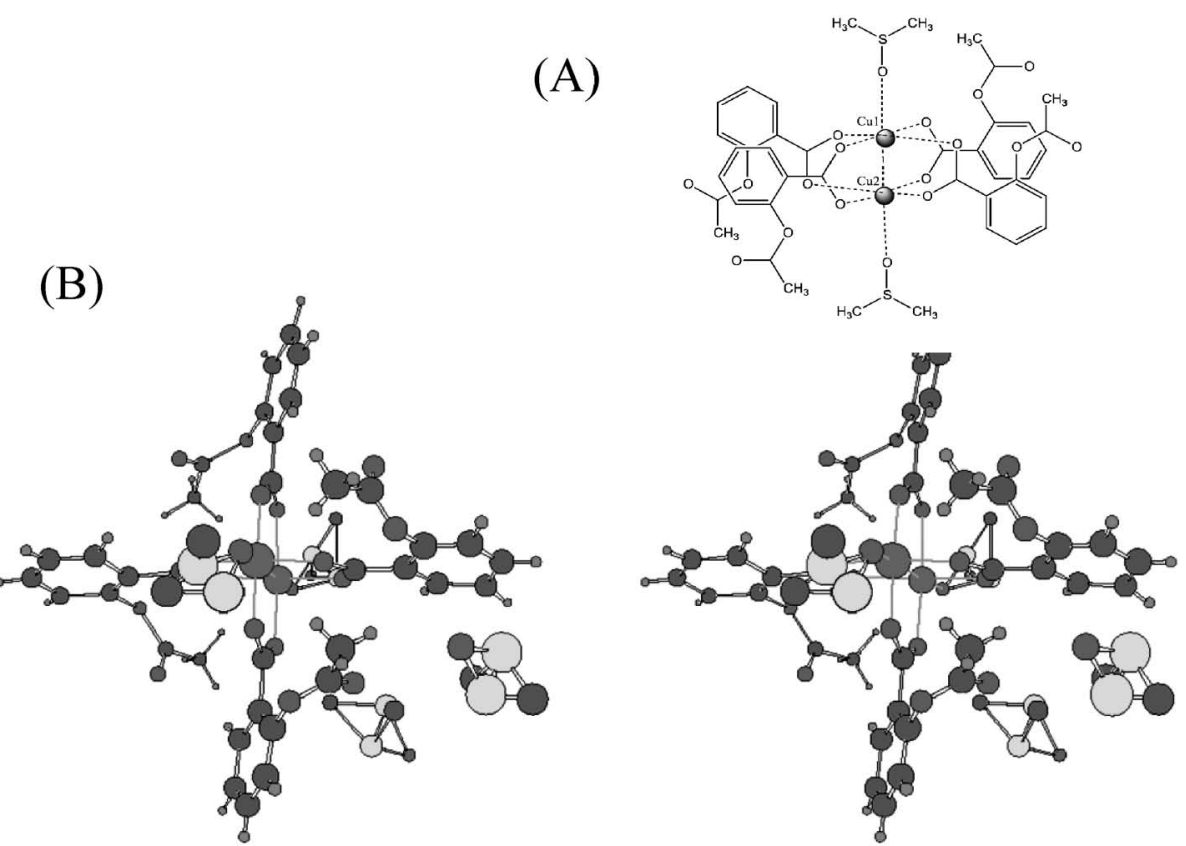

Fig. 2. The Structures of Dinuclear Copper-aspirinat Complex

(A) Chemical structure, (B) structure by X-ray structure analysis. (from ref. (10)) 
$(\mathrm{DMSO})_{2}>\mathrm{CuSO}_{4}$ の順となった。 これらの錯体を $\mathrm{HR}-1$ ヘアレスマウスに経口投与すると， $\mathrm{Cu}_{2}$ $(\mathrm{asp})_{4}(\mathrm{DMSO})_{2}$ は皮膚の UVA 傷害を有意に防御 することが分かった。このとき，血中及び皮膚組織 中の銅濃度も上昇していた。 $\mathrm{Cu}_{2}(\mathrm{asp})_{4}(\mathrm{DMSO})_{2}$ の分配係数 $\left(\mathrm{K}=\mathrm{C}_{\text {オレィルアルコール }} / \mathrm{C}_{\text {水 }}\right)$ は， $\mathrm{K}=1.3$, $\log \mathrm{K}=0.1$ であることを考えると， $\mathrm{Cu}_{2}(\mathrm{asp})_{4}$ $(\mathrm{DMSO})_{2}$ 錯体は脂溶性であり，したがつて錯体が このままの形で一部が皮膚組織へ輸送され細胞膜に 到達し，そこに分布して ROS を消去すると紫外線 から皮膚を防御すると考えた。ささら，3 種類の化 合物を健常ラットに単回静脈内投与して，血中の $\mathrm{Cu}^{2+}$ について ESR スペクトルを経時的に計測して 金属動態解析（metallokinetics）をした. $\mathrm{Cu}^{2+} に$ 関するクリアランス曲線を解析して，種々のパラ メータを算出した。例えば，平均滞留時間(分)は,

$\mathrm{Cu}_{2}(\mathrm{asp})_{4}(\mathrm{DMSO})_{2} \quad 19.9 \pm 2.7, \mathrm{Cu}(\mathrm{sal})_{2} \quad 6.2 \pm$ 0.8 ，酢酸銅 $\left(\mathrm{Cu}(\text { ace })_{2}\right) 3.1 \pm 0.7$ となった。 $\mathrm{Cu}_{2}$ $(\mathrm{asp})_{4}(\mathrm{DMSO})_{2}$ が最も高い皮膚障害抑制効果を示 したことは，本錯体の血液さらには各組織への分布 の高さと関連づけられた。

こうして $\mathrm{Cu}_{2}(\mathrm{asp})_{4}(\mathrm{DMSO})_{2}$ の化学的・生物学 的抗酸化作用が明らかになったため，ラットの心血 管障害が改善できるかどうかに関して研究が展開さ れた. ${ }^{12)}$ 老化ラット（生後 22 力月，体重 460-580 g) はヤングアダルトラット（生後 3 カ月，体重 200$250 \mathrm{~g}$ ）と比べて，左心室の収縮性及び血管内皮に 著しい傷害がみられる。そこで, $\mathrm{Cu}_{2}(\mathrm{asp})_{4}(\mathrm{DMSO})_{2}$ を 3 週間にわたり $200 \mathrm{mg} / \mathrm{kg}$ 体重の割合で経口投 与したところ，老化ラットの一酸化窒素合成酵素 （nitric oxide synthase, NOS） レベルが低下するとと もに心機能及びアセチルコリンによる血管拡張性が 著しく改善された. ${ }^{12)}$ これに関連して，バナジル-1オキシー2-ピリジンチオレート錯体（VO $\left.(\mathrm{opt})_{2}\right)$ は 心筋梗塞や高血圧により生じる心肥大を抑制できる 可能性が示され，この分野における金属錯体の有用 性に関する成果が蓄積されている. ${ }^{13)}$ 一方，銅イ才 ンへの選択的配位子であるトリエチルテトラミン （triethyltetramine）は，2 型糖尿病患者の左心室の 肥大を改善し，また糖尿病動物の心疾患の病態の進 行を抑制できることが報告されている. ${ }^{14)}$ 本配位子 は，これまで銅過剰症として知られているウイルソ ン病の治療薬として銅の体外除去剂として用いられ
ている，上で紹介した銅と糖尿病との関連性の研究 では，銅の本質的役割はまだ明らかにされていない ようであるが，重要な課題が隠されているように思 われる。

\section{3. 銅ーピコリン酸錯体による 1 型類似糖尿病ラ} ットの血糖降下作用

カナダのバンティング（Banting 1891-1941） と ベスト（Best 1899-1878）により糖尿病治療薬イン スリンが発見される 23 年も前の 1899 年に，フラン スの内科医がバナジウム（V) 化合物，メタバナジ ン酸ナトリウム $\left(\mathrm{NaVO}_{3}\right)$ を用いて糖尿病患者の 病態を部分的に改善させた着想には，驚くべきもの がある。しかし，科学的根拠に基づいて $\mathrm{NaVO}_{3} や$ 硫酸バナジウム $\left(\mathrm{VOSO}_{4}\right)$ を経口投与して糖尿病 患者を治療しようとする報告は 20 世紀まで待たね ばならなかった. ${ }^{15)}$ そして 1980 年以後，バナジウ ム以外に亜鉛，マンガン，銅，クロムやタングステ ン化合物が，in vitro インスリン作用及び実験糖尿 病動物や糖尿病患者で in vivo 血糖降下作用を示す

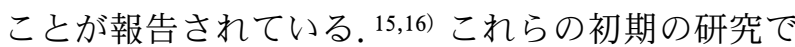
は，無機化合物のみが用いられていたが，筆者のグ ループは，無機イオンを錯体化することにより分配 係数が高くなり，したがって生体組織に取り込まれ 易くなり，高いインスリン様作用や抗糖尿病作用が 期待されると考えた。1990 年に，バナジルーシステ インメチルエステル $\left(\mathrm{VO}(\mathrm{cysm})_{2}\right)$ 錯体を経口投与 するとストレプトゾシン（STZ）により誘導される 1 型類似糖尿病ラット（STZ-ラット）の高血糖值 を正常化できることを世界で初めて見い出した. ${ }^{17)}$ この発見を契機に，抗糖尿病金属錯体（anti-diabetic-metallocomplexes）の開発研究に取り組むこ ととした。1995 年に, 新しい経口活性錯体バナジ ルーピコリン酸（VO $\left.(\mathrm{pa})_{2}\right)$ 錯体が強い血糖降下作 用を持っていることを見い出した. ${ }^{18)}$ ピコリン酸を 金属イオンに結合させるメリットは 2 点ある．第 1 は，ピコリン酸はアミノ酸トリプトファンの代謝産 物の 1 つであり，したがって毒性は高くない，第 2 点はピコリン酸を経口投与すると小腸部位で金属个 オンの吸収性を促進する。そこで，VO $(\mathrm{pa})_{2}$ 錯体 よりもより有効性の高い錯体を求めて，第 1 系列の 遷移元素を中心金属にした錯体を合成し，in vitro 試験としてラットの遊離肝細胞を用いて細胞からの 脂肪酸放出抑制作用及び STZ-ラットに単回腹腔内 
投与して血糖降下作用を評価した。 ${ }^{19)}$ In vitro 評価 では, $\mathrm{Mn}(\mathrm{pa})_{2}>\mathrm{Cu}(\mathrm{pa})_{2}>\mathrm{VO}(\mathrm{pa})_{2}>\mathrm{Fe}(\mathrm{pa})_{2}>$ $\mathrm{Fe}(\mathrm{pa})_{3}>\mathrm{Zn}(\mathrm{pa})_{2}$ の順に活性が低下した。この中 で $\mathrm{Mn}(\mathrm{pa})_{2}$ が最も高い活性を示したが， $\mathrm{Mn}(\mathrm{pa})_{2}$ とラット肝臓の培養細胞との相互作用を調べたとこ ろ，添加した錯体濃度の上昇とともに細胞の生存率 が低下した。しかし， $\mathrm{Cu}(\mathrm{pa})_{2}$ や $\mathrm{VO}(\mathrm{pa})_{2}$ 錯体で は全く影響はみられなかった。このため，次に活性 の高い $\mathrm{Cu}(\mathrm{pa})_{2}$ と $\mathrm{VO}(\mathrm{pa})_{2}$ の血糖降下作用を検討 した. $\mathrm{Cu}(\mathrm{pa})_{2}$ 錯体は $3 \mathrm{mg}(0.047 \mathrm{mmol}) \mathrm{Cu} / \mathrm{kg}$ 体 重の割合で投与すると 12-13 時間後に正常血糖值を 示したのに対して, $\mathrm{VO}(\mathrm{pa})_{2}$ は $10 \mathrm{mg}(0.20 \mathrm{mmol})$ $\mathrm{V} / \mathrm{kg}$ 体重でもほぼ正常血糖值を示すことが分かっ た.これらの結果及び本錯体の作用機構がグルコー 又輸送体の細胞膜表面への移動を誘導する PI3-K (phosphoinositol-3-kinase)/Akt/PKB (protein kinase B）経路を活性化することが推定されたことなどか ら, $\mathrm{Cu}(\mathrm{pa})_{2}$ 錯体（Fig. 3) は抗糖尿病錯体の 1 つ として医薬品開発への高い可能性を持っていると考 えている. ${ }^{19)}$

一方，筆者のグループでは，薬物送達系（drug delivery system）を利用した抗糖尿病金属錯体の開 発研究を進め，錯体をミニカプセル等に詰め込み動 物に経口投与して錯体の血中濃度上昇を図るととも に，金属イオンへの配位子にも注目して研究を行っ た．生分解性及び生体適合性を持つ高分子配位子に は，薬物標的特異性，薬物毒性の軽減化，薬物吸収 速度の改善そして生体での錯体の分解抑制などの有 用性が挙げられる。この目的のために，ヒトや環境 に毒性を示さないアミノ酸 $\gamma$-グルタミン酸の高分 子化合物である $\gamma$-PGA（ $\gamma$-polyglutamic acid）を用 い，バナジル錯体や銅錯体を合成した。それらの物 性を詳しく解析し，続いて in vitro インスリン様作 用や in vivo 血糖降下作用を研究した。VO- $\gamma$-PGA 錯体は 16 日間 $10 \mathrm{mgV} / \mathrm{kg}$ 体重の割合で経口投与す ると高い血糖降下作用を示すとともに，長期の糖尿 病状態を示す血中の糖化へモグロビン $\left(\mathrm{HbA}_{1 \mathrm{c}}\right)$ レ

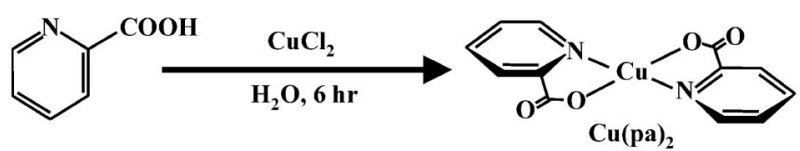

Fig. 3. Preparation Method and Structure of Copper(II) picolinate Complex (from ref. (19))
ベルもかなり改善し，医薬品として開発できる可能 性が示された。 ${ }^{20)} \mathrm{Cu}-\gamma$-PGA 錯体に関しては，in vitroの結果からは銅イオンと有意差がみられてい ないため, ${ }^{21)}$ 効果的な錯体構造をデザインすること を検討している。

\section{4. 銅イオンのグルコース吸収阻害作用と抗糖尿 病作用}

糖尿病は, 食事療法, 運動療法そしてインスリン 注射を含めた薬物療法などにより予防・治療が行わ れている。薬物療法には多種類の医薬品が用いられ ているが，その中で $\alpha$-グルコシダーゼ阻害剤もよ く用いられている。 $\alpha$-グルコシダーゼ阻害剤は, 1,4$\alpha$-グルコシド結合を持つ二糖類，例えばスクロース （ショ糖，砂糖，グルコース＋フルクトース）やマ ルトース（麦芽糖，グルコース+グルコース）が小 腸で $\alpha$-グルコシダーゼにより単糖類に分解される 酵素反応を触媒する，小腸でグルコースが吸収され ないと食後血糖值の上昇や過剩なインスリン分泌が 抑制される。したがって， $\alpha$-グルコシダーゼ阻害剤 を服用するとインスリン投与量が下げられるだけで なく, インスリン産生に係わる膵臓 $\beta$ 細胞の機能 を軽減することができる，現在，臨床的に用いられ ている $\alpha$-グルコシダーゼ阻害剤には，acarbose, voglibose や miglitol などがある. 22,23)

いくつかの金属イオンやその錯体が実験糖尿病治 療薬の候補として研究されていることは，既に述べ た。これらの錯体は全身に分布して，細胞のインス リンシグナル伝達系に作用し，“アンサンブル機構” により細胞内へのグルコースの取り込みを促進する

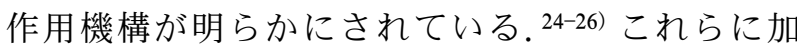
え，筆者のグループでは，金属イオンとその錯体が $\alpha$-グルコシダーゼ阻害剤活性を有しているかどうか を検討し，新たな機能が見い出せるかどうかを評価 することとした. ${ }^{27)}$ 本研究では, 酵母（Saccharomyces sp.) 及びラット小腸由来の $\alpha$-グルコシダー ゼを用いた。ラット小腸アセトン粉末を Sephadex G-100 を用いて部分精製したところ，低分子画分に 粗製品の約 100 倍の活性が検出された．本画分を用 いて $\alpha$-グルコシダーゼ阻害作用を調べた。 11 種類 の金属イオンを用いて酵母 $\alpha$-グルコシダーゼへの 阻害作用を検討したところ，2 価金属イオン $\mathrm{Cu}^{2+}$, $\mathrm{Zn}^{2+}, \mathrm{VO}^{2+}$ 及び $\mathrm{Ni}^{2+}$ （すべて硫酸化合物）では, それぞれ acarbose の約 1000, 100, 4 及び 2 倍の活 
性を示した。しかし，ラット小腸由来の $\alpha$-グルコ シダーゼに対しては， $\mathrm{Cu}^{2+}$ と $\mathrm{Zn}^{2+}$ ではそれぞれ 0.6 及び 0.05 倍の活性しか示さなかった．種々の金

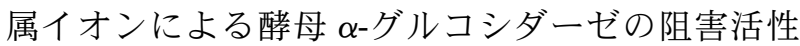
の大きさは，Irving-Williams の安定度序列にほぼ 一致したため，活性は金属イオンと酵素との結合に よると推定された。両 $\alpha$-グルコシダーゼの活性中心 の構造が解析されれば，金属イオンの触媒機能を議 論できると期待している.

両 $\alpha$-グルコシダーゼに対して最も強い阻害活性 を示した銅イオンに関して，耐糖能試験を試みた。 ddy 系マウスに $0.08 \mathrm{mmol} / \mathrm{kg}$ 体重及び $0.24 \mathrm{mmol} /$ $\mathrm{kg}$ 体重の割合で $\mathrm{CuSO}_{4}$ 及び acarbose を経口投与 し，30 分後にグルコース又はスクロース（砂糖） を $2 \mathrm{~g} / \mathrm{kg}$ 体重の割合で経口的に与え，経時的に血 中グルコース濃度を測定した。グルコースを与えた グループでは $\mathrm{CuSO}_{4}$ と acarbose 投与による差はみ られなかったが，スクロースを与えたグループでは $\mathrm{CuSO}_{4}$ 及び acarbose ともに，明らかに投与量に依 存して血糖降下作用を示した，以上の結果から，銅 イオンは in vitro で $\alpha$-グルコシダーゼ阻害作用を示 すのみならず，in vivo で血糖降下作用を示し，そ の活性の強さは acarbose に匹敵するものであっ た，既に述べたように，銅錯体は経口投与により血 糖降下作用を示すが，この作用には消化管内での $\alpha$-グルコシダーゼの阻害作用も寄与していると推定 される. 今後, $\alpha$-グルコシダーゼ阻害作用を in vitro 活性評価系に加え，より活性の高い抗糖尿病治療薬 の研究開発を目指すことは重要であろう。

謝辞本研究は，筆者が平成 16 年度一平成 18 年度（2004-2006 年）の 3 年間にわたり，文部科学 省科学研究費補助金（特別推進研究）の交付を受け て，主として京都薬科大学薬学部で行われたもので ある．文部科学省及び本研究に参加して頂いた大学 教員, 各研究機関の研究者, 大学院生及び学部学生 諸氏に感謝を申し上げる.

\section{REFERENCES}

1) Bowman-James K., Acc. Chem. Res., 38, 671678 (2005).

2) Sakurai H., Yoshikawa Y., Yasui H., Chem. Soc. Rev., 37, 2383-2392 (2008).
3) Sakurai H., J. Health Sci., 56, 129-143 (2010).

4) Lloyd N. C., Morgan H. W., Nicholson B. K., Ronimis R. S., Angew. Chem. Int. Ed., 44, 941-944 (2005).

5) Nagahashi S., "Mineraru Biryougenso no Eiyougaku," eds. by Suzuki T., Wada O., Daiichi Shuppan Co., Ltd., Tokyo, 1994, pp. 97-411.

6) Hiromura M., "Seimeigenso Jiten," ed. by Sakurai H., Ohmsha, Tokyo, 2006, pp. 17-21.

7) Lutsenko S., Curr. Opin. Chem. Biol., 14, 211 -217 (2010).

8) Muscoli C., Cuzzocrea S., Riley D. P., Zweier J. L., Thiemermann C., Wang Z. Q., Salvemini D., Br. J. Pharmacol., 140, 445-450 (2003).

9) Itami C., Matsunaga H., Sawada T., Sakurai H., Kimura Y., Biochem. Biophys. Res. Commun., 197, 536-541 (1993).

10) Fujimori T., Yamada S., Yasui H., Sakurai H., In Y., Ishida T., J. Biol. Inorg. Chem., 10, 831-841 (2005).

11) Fujimori T., Yasui H., Hiromura M., Sakurai H., Exp. Dermatol., 16, 746-752 (2007).

12) Radovits T., Gerö D., Lin L. N., Loganathan S., Hoppe-Tichy T., Szabó C., Karck M., Sakurai H., Szabó G., Rejuvenation Res., 11, 945-956 (2008).

13) Bhuiyan M. S., Fukunaga K., J. Pharmacol. Sci., 110, 1-13 (2009).

14) Cooper G. J., Young A. A., Gamble G. D., Occleshawa C. J., Dissanayake A. M., Cowan B. R., Brunton D. H., Baker J. R., Phillips A. R., Frampton C. M., Roppitt S. D., Doughty R. N., Diabetologia, 52, 715-722 (2009) .

15) Sakurai H., Expert Opin. Drug Discov., 2, 873 -887 (2007).

16) Sakurai H., J. Jpn. Soc. Med. Use Funct. Foods, 5, 409-414 (2009).

17) Sakurai H., Tsuchiya K., Nukatsuka M., Kawada J., Ishikawa S., Yoshida H., Komatsu M., J. Clin. Biochem. Nutr., 8, 193-200 (1990).

18) Sakurai H., Fujii K., Watanabe H., Tamura H., Biochem. Biophys. Res . Commun., 214, 1095-1101 (1995).

19) Yasumatsu N., Yoshikawa Y., Adachi Y., Sakurai H., Bioorg. Med. Chem., 15, 4917- 
4922 (2007).

20) Karmaker S., Saha T. K., Yoshikawa Y., Yasui H., Sakurai H., J. Inorg. Biochem., 100, 1535-1546 (2006).

21) Karmaker S., Saha T. K., Sakurai H., Macromol. Biosci., 7, 456-466 (2007).

22) Rosak C., Mertes G., Curr. Diabetes Rev., 5, 157-164 (2009).

23) Benalla W., Bellahcen S., Bnouham M., Curr. Diabetes Rev., 6, 247-254 (2010).

24) Nakayama A., Hiromura M., Adachi Y.,
Sakurai H., J. Biol. Inorg. Chem., 13, 675684 (2008).

25) Hiromura M., Adachi Y., Machida M., Hattori M., Sakurai H., Metallomics, 1, 92-100 (2009).

26) Sakurai H., Katoh A., Kiss T., Jakusch T., Hattori M., Metallomics, 2, 670-682 (2010).

27) Yoshikawa Y., Hirata R., Yasui H., Hattori M., Sakurai H., Metallomics, 2, 67-73 (2010) 